Piotr SiŁKA

Polska Akademia Nauk

\title{
Typologia miast ze względu na potencjał innowacyjny
}

Tematyka innowacyjności bardzo zyskała na znaczeniu w ostatnich latach, zarówno w dyskusjach naukowych jak i w praktyce, gdzie pojęcie innowacji stało się kluczowym zagadnieniem wykorzystywanym w rozwoju podmiotów gospodarczych. Popularność tej tematyki przyczyniła się jednak do wieloznaczności wielu podstawowych pojęć oraz trudności w wyłonieniu jednolitej metodologii badań. Syntetyczny opis kolejno tworzonych modeli procesu innowacyjnego przedstawiają D. Marinova i J. Philimore (2003). Obecnie najbardziej rozpowszechniony w Polsce jest model środowiska innowacyjnego rozumianego jako szczególnie złożona infrastruktura badawcza, kulturowa i instytucjonalna, która sprzyja dynamizowaniu i pojawianiu się innowacji (Markowski 2005). Na bazie kolejnych modeli powstała koncepcja systemów innowacyjnych, w ramach której funkcjonuje pojęcie potencjału innowacyjnego, będącego głównym przedmiotem badania w prezentowanym artykule.

Niniejsze opracowanie jest z jednej strony próbą szerszej analizy potencjału innowacyjnego (wzbogaconej o nie analizowane dotychczas czynniki), a z drugiej zbadania tego zagadnienia na niższym poziomie agregacji przestrzennej (miasta na prawach powiatu), co dotychczas nie miało miejsca.

\section{ZAKRES PRZESTRZENNY I CZASOWY}

Zakres przestrzenny badania obejmuje 65 miast na prawach powiatu (miasta $\mathrm{w}$ granicach administracyjnych). Należy wspomnieć, iż Warszawa uzyskała status miasta na prawach powiatu w dniu 27 października 2002 r.; w latach 1999-2002 istniały równolegle powiat warszawski i miasto stołeczne Warszawa (związek komunalny gmin). Jednakże ze względu na potencjał skupiony przez stolicę, a także fakt, że w kolejnych latach badania ma ona status miasta na prawach powiatu, włączono do analizy miasto Warszawa. W przypadku roku 2000 dane pochodzą zatem z powiatu warszawskiego. W grupie badanych miast nie uwzględniono miasta Wałbrzych, które z dniem 1 stycznia 2003 r. utraciło prawa miasta na prawach powiatu. 


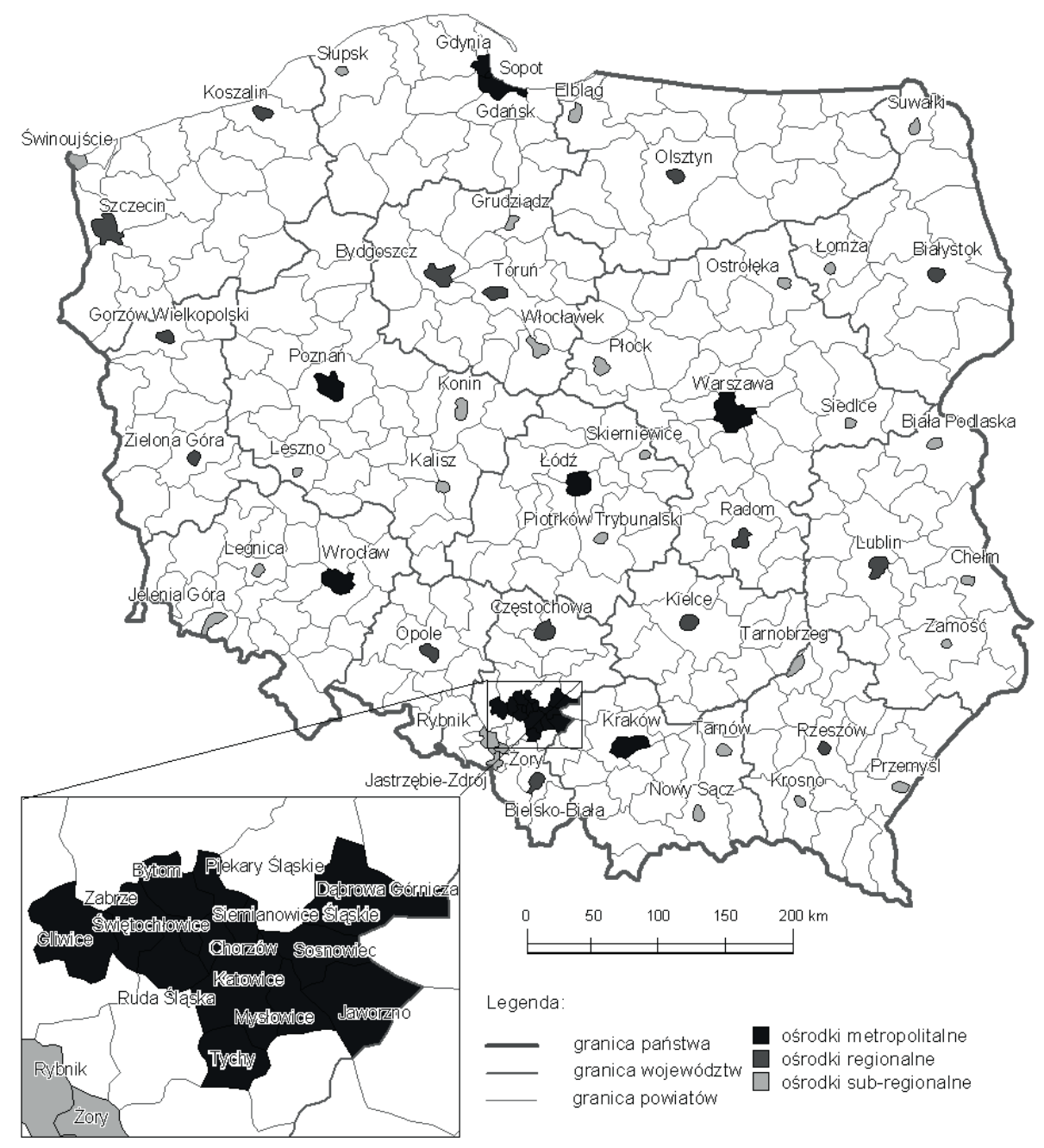

Ryc. 1. Analizowane miasta na prawach powiatu w podziale na trzy grupy

Źródło: opracowanie własne

Wybór miast (ryc. 1) podyktowany jest kilkoma powodami. Po pierwsze, jednostki te posiadają taki sam status prawny, co umożliwia porównywanie ich pod względem formalnym; po drugie, pod względem liczby ludności jest to zdecydowana większość miast Polski; po trzecie, na tym poziomie agregacji przestrzennej jest możliwe uzyskanie danych statystycznych niezbędnych do analizy. Autor starając się uniknąć powtórzeń w odniesieniu do wszystkich powyższych jednostek używa zamiennie określeń miasto i ośrodek.

Poszczególne analizy prowadzone były na zbiorze 65 miast na prawach powiatu, jednakże typologia miast jest prezentowana dla zbioru miast gdzie dwa ośrodki: Trójmiasto 
(Sopot, Gdynia, Gdańsk) oraz Konurbacja Górnośląska, są traktowane jako pojedyncze obszary metropolitalne ${ }^{1}$, zgodnie z ustaleniami tzw. MEGA - Europejskich Metropolitalnych Obszarów Wzrostu.

Zakres czasowy obejmuje lata 2000, 2004 i 2008 z dwóch podstawowych powodów. Po pierwsze, ujęcie w badaniu możliwie dużego przedziału czasowego miało pokazać dynamikę zmian, po drugie, uwzględniono okres po 2004 roku, kiedy to Polska wstąpiła do Unii Europejskiej.

\section{ŹRÓDŁA DANYCH}

Najważniejszym źródłem danych statystycznych w niniejszym opracowaniu jest Główny Urząd Statystyczny (GUS). Jako że brak jest tego typu danych w ogólnodostępnych źródłach zdecydowano się na zakup niepublikowanych danych statystycznych. Dotyczyły one trzech podstawowych zagadnień: działalności badawczej i rozwojowej, działalności innowacyjnej przedsiębiorstwa oraz struktury przedsiębiorstw. Dane te stanowiły ponad połowę wskaźników wykorzystanych w syntetycznym wskaźniku potencjału innowacyjnego. Oprócz powyższych danych wykorzystano także informacje ogólnodostępne z publikacji „Powiaty w Polsce" wydawanej również przez GUS.

Dodatkowo wykorzystano dane z następujących instytucji:

- Ośrodek Przetwarzania Informacji,

- Urząd Patentowy Rzeczpospolitej Polskiej,

- Baza Cordis,

- Naukowa i Akademicka Sieć Komputerowa (NASK),

- Stowarzyszenie Organizatorów Ośrodków Innowacji i Przedsiębiorczości.

\section{Metodologia}

Proces badawczy można podzielić na trzy etapy. Pierwszy etap to dobór odpowiednich mierników dla trzech przekrojów czasowych i dla wszystkich obiektów analizowanego zbioru (65 miast) mogących w sposób poprawny merytorycznie opisać analizowane zjawisko. Na podstawie przeprowadzonej kwerendy opracowano zestaw mierników, które można wykorzystać w badaniu i rozpoczęto proces pozyskiwania danych, a następnie konfrontowania ich z zasadami prawidłowego doboru cech przyjętymi w literaturze, czyli kryterium merytorycznym, formalnym i statystycznym (Zeliaś 2000, Strahl 2006). Lista mierników (podzielonych na pięć podstawowych komponentów) branych pod uwagę jest następująca:

${ }^{1}$ Autor zdaje sobie sprawę, że przedstawienie obszarów metropolitalnych zawężonych do granic administracyjnych miast jest dużym uproszczeniem tego zagadnienia, jednakże dostępne dane uniemożliwiły wyodrębnienie tych obszarów w sposób bardziej poprawny metodologicznie, a ponadto należy zaznaczyć, iż delimitacja obszarów metropolitalnych nie jest celem tego opracowania. 


\section{- Sektor nauki (NAUKA)}

- liczba nauczycieli akademickich na 1000 osób w wieku produkcyjnym,

- liczba szkół wyższych na 10000 podmiotów gospodarczych,

- liczba doktoratów na 10000 osób w wieku produkcyjnym,

- liczba habilitacji na 10000 osób w wieku produkcyjnym,

- liczba studentów na szkołę wyższą,

- liczba absolwentów na szkołę wyższą.

\section{- Sektor badań i rozwoju $(B+R)$}

- liczba zespołów w Programach Ramowych na 100000 jednostek B+R i szkół wyższych,

- liczba jednostek B+R na 10000 podmiotów gospodarczych,

- liczba osób zatrudnionych w B+R na jednostkę $\mathrm{B}+\mathrm{R}$,

- nakłady ogółem w B+R na jednostkę B+R,

- wartość aparatury badawczej w B+R na jednostkę B+R.

\section{- Przedsiębiorstwa i instytucje wspierające (PRZED/INSTYT)}

- liczba zgłoszeń wzorów użytkowych na 10000 osób w wieku produkcyjnym,

- liczba zgłoszeń wynalazków na 10000 osób w wieku produkcyjnym,

- liczba domen na 100 podmiotów gospodarczych,

- liczba instytucji otoczenia innowacyjnego na 100000 podmiotów gospodarczych,

- liczba podmiotów gospodarczych wspierających działalność gospodarczą na 1000 podmiotów gospodarczych.

\section{- Przedsiębiorstwa przemyslowe (PRZEMYSE)}

- nakłady innowacyjne w przemyśle na 100 podmiotów gospodarczych w sektorach C, D, E,

- liczba przedsiębiorstw, które dokonały zakupu technologii na 1000 podmiotów gospodarczych w sektorach $\mathrm{C}, \mathrm{D}, \mathrm{E}$,

- współpraca z innymi przedsiębiorstwami i instytucjami w zakresie działalności innowacyjnej na 1000 podmiotów gospodarczych w sektorach C, D, E,

- linie produkcyjne (technologiczne) sterowane komputerem na 1000 podmiotów gospodarczych w sektorach C, D, E,

- linie produkcyjne (technologiczne) automatyczne na 1000 podmiotów gospodarczych w sektorach C, D, E.

\section{- Struktura przedsiębiorstw (STRUKTURA)}

- liczba przedsiębiorstw wysokiej techniki na 100000 osób w wieku produkcyjnym,

- liczba przedsiębiorstw średniowysokiej techniki na 100000 osób w wieku produkcyjnym,

- liczba przedsiębiorstw średnioniskiej techniki na 100000 osób w wieku produkcyjnym,

- liczba przedsiębiorstw usługowych wysokiej techniki na 100000 osób w wieku produkcyjnym.

Szczególnie kryteria statystyczne uniemożliwiły wykorzystanie wszystkich cech, stąd ich liczba zmniejszyła się do $21 \mathrm{w}$ dalszym etapie badania.

Kolejny etap analizy to badanie struktury potencjału innowacyjnego za pomocą analizy składowych głównych. W pierwszej kolejności zbadano, które zmienne mają rozkład normalny, gdyż tylko takie mogą zostać włączone do analizy. Do sprawdzenia rozkładu 
poszczególnych cech zastosowano test Kołomogrowa-Smirnowa. Przeprowadzone testy wykazały, iż cześć zmiennych ma istotny wpływ na wynik tekstu. Z tego względu usunięto 4 miasta (Gliwice, Sopot, Płock, Warszawa), które zaburzały swymi wynikami kilka cech. Wyeliminowano także z dalszego badania 5 zmiennych, dla których mimo usunięcia powyższych miast test Kołomogrowa-Smirnowa był istotny.

Ostatecznie w analizie składowych głównych wykorzystano 62 ośrodki, które były scharakteryzowane przez 16 zmiennych dotyczących potencjału innowacyjnego w trzech momentach czasowych. Kolejnym krokiem było przekształcenie przygotowanej macierzy w nowe zmienne określane składowymi głównymi (czynnikami). Zgodnie z metodą kryterium osypiska, do dalszych analiz wykorzystano 3 składowe główne.

W ostatnim etapie badawczym w oparciu o dwie składowe główne zinterpretowane $\mathrm{w}$ analizie struktury potencjału innowacyjnego, przeprowadzono typologię miast. Autor zdecydował się pominąć trzecią składową główną, ze względu na trudności w jednolitej jej interpretacji w trzech momentach czasowych, a także powtórzenie przez nią pewnych informacji zawartych w pierwszej składowej głównej. Poza tym dwa pierwsze czynniki obrazują główny podział ze względu na rodzaj potencjału innowacyjnego i pozwalają na wydzielenie interesujących badacza typów.

W przypadku obu składowych głównych dokonano podziału na 2 klasy (tab. 1) z tą jednak różnicą, iż w procesie porządkowania liniowego przy pierwszej składowej głównej kierunek ujemny oznacza wyższy potencjał danego charakteru.

Tab. 1. Określenie klas typologicznych

\begin{tabular}{|l|l|l|}
\hline Klasa typologiczna & I składowa główna & II składowa główna \\
\hline I & wysoki & wysoki \\
\hline II & wysoki & niski \\
\hline III & niski & wysoki \\
\hline IV & niski & niski \\
\hline
\end{tabular}

Źródło: opracowanie własne

Podział na klasy przedstawia się następująco (średnia standaryzowanych wartości głównych wynosi 0):

- wysoki potencjał gdy $\mathrm{V}_{1}<\mathrm{S}\left(\mathrm{V}_{1}\right)$ oraz $\mathrm{V}_{2}>\mathrm{S}\left(\mathrm{V}_{2}\right)$,

- niski potencjał gdy $\mathrm{V}_{1}>\mathrm{S}\left(\mathrm{V}_{1}\right)$ oraz $\mathrm{V}_{2}<\mathrm{S}\left(\mathrm{V}_{2}\right)$.

Na podstawie powyższego podziału łącznie uzyskano 4 typy potencjału innowacyjnego dla wszystkich analizowanych momentów czasowych.

\section{WYNIKI ANALIZY SKŁADOWYCH GŁÓWNYCH}

Analiza 16 cech potencjału innowacyjnego dla 62 miast pozwoliła na wydzielenie i zinterpretowanie trzech składowych głównych opisujących strukturę potencjału innowa- 
cyjnego. W niniejszym artykule opisane zostaną jedynie dwie pierwsze składowe, które są kluczowe dla opracowania typologii. Łącznie w roku 2000 wyjaśniają one 53,3\% zasobów informacyjnych zmiennych wejściowych (skumulowana wartość wariancji). W roku 2004 wartość ta wzrosła do 54,0\%, zaś w ostatnim przekroju czasowym aż do 55,3\%.

Według pierwszej składowej głównej wyjaśnione jest w roku 2000 - 29,5\%, 2004 29,9\% i 2008 - 29,0\% zmienności wszystkich analizowanych cech. Współczynniki determinacji dla tej składowej głównej przyjmują najwyższe wartości dla następujących cech (tab. 2):

- liczba zgłoszeń wynalazków na 10000 osób w wieku produkcyjnym,

- liczba domen na 100 podmiotów gospodarczych,

- liczba nauczycieli akademickich na 1000 osób w wieku produkcyjnym,

- liczba przedsiębiorstw wysokiej techniki na 1000 mieszkańców,

- liczba zgłoszeń wzorów użytkowych na 10000 osób w wieku produkcyjnym.

Wyżej przedstawione relacje dla tej składowej głównej są najważniejsze w każdym z trzech analizowanych przekrojów czasowych. Wyjątkiem są zgłoszenia wzorów użytkowych, które ustępują miejsca w roku 2000 innym relacjom. Warto jednak zwrócić uwagę na pojawianie się też innych ważnych związków z takimi zmiennymi jak liczba jednostek badawczo-rozwojowych czy liczba studentów.

Tab. 2. Współczynniki determinacji pomiędzy pierwszą składową główną a cechami analitycznymi dla lat 2000, 2004, 2008

\begin{tabular}{|l|c|c|c|}
\hline \multicolumn{1}{|c|}{ Cecha } & $\mathbf{2 0 0 0}$ & $\mathbf{2 0 0 4}$ & $\mathbf{2 0 0 8}$ \\
\hline NAUCZ & $\mathbf{0 , 6 5 5}$ & $\mathbf{0 , 5 9 1}$ & $\mathbf{0 , 6 9 5}$ \\
\hline SZKOŁY & 0,133 & 0,018 & 0,027 \\
\hline STUD & $\mathbf{0 , 4 3 9}$ & 0,289 & 0,333 \\
\hline NAK_B+R & 0,108 & 0,218 & 0,144 \\
\hline APR_B+R & 0,217 & 0,096 & 0,168 \\
\hline JED_B+R & 0,252 & 0,280 & 0,376 \\
\hline DOMENY & $\mathbf{0 , 6 3 4}$ & $\mathbf{0 , 7 9 5}$ & $\mathbf{0 , 6 4 9}$ \\
\hline WYNAL & $\mathbf{0 , 5 0 6}$ & $\mathbf{0 , 6 3 6}$ & $\mathbf{0 , 6 4 3}$ \\
\hline WZORY & 0,277 & $\mathbf{0 , 4 5 3}$ & $\mathbf{0 , 4 3 5}$ \\
\hline OT_BZ & 0,278 & 0,244 & 0,428 \\
\hline LIN_AUT & 0,001 & 0,009 & 0,016 \\
\hline ZAK_TECH & 0,013 & 0,001 & 0,001 \\
\hline WSP_PRZEM & 0,028 & 0,000 & 0,006 \\
\hline WYS_TECH & $\mathbf{0 , 5 1 7}$ & $\mathbf{0 , 4 8 1}$ & $\mathbf{0 , 4 8 4}$ \\
\hline ŚRED_W_TECH & 0,294 & 0,345 & 0,169 \\
\hline ŚRED_N_TECH & 0,373 & 0,325 & 0,087 \\
\hline
\end{tabular}

Źródło: opracowanie własne

*pogrubieniem wyróżniono 5 cech o najwyższych wartościach w analizowanych momentach czasowych 
Przedstawione relacje pozwalają interpretować składową główną jako składową czynników rozwiniętego sektora badawczo-rozwojowego, charakteryzującego się dobrą jakością kapitału ludzkiego.

Druga składowa główna wyjaśnia w kolejnych przekrojach czasowych odpowiednio $13,5 \%, 14,9 \%$ oraz 14,1\% zmienności wszystkich analizowanych cech. Współczynniki determinacji dla drugiej składowej głównej przyjmują najwyższe wartości dla następujących cech (tab. 3):

- liczba zakupionych technologii na 1000 przedsiębiorstw sektora C, D, E,

- liczba współpracujących przedsiębiorstw na 1000 przedsiębiorstw sektora C, D, E,

- liczba linii produkcyjnych (technologicznych) sterowanych automatycznie na 1000 przedsiębiorstw sektora $\mathrm{C}, \mathrm{D}, \mathrm{E}$.

Przedstawione związki pozwalają interpretować składową główną jako składową czynników zasobów przedsiębiorstw przemysłowych.

Tab. 3. Współczynniki determinacji pomiędzy drugą składową główną a cechami analitycznymi dla lat 2000, 2004, 2008

\begin{tabular}{|l|l|l|l|}
\hline \multicolumn{1}{|c|}{ Cecha } & $\mathbf{2 0 0 0}$ & $\mathbf{2 0 0 4}$ & $\mathbf{2 0 0 8}$ \\
\hline NAUCZ & 0,001 & 0,111 & 0,019 \\
\hline SZKOŁY & 0,006 & 0,072 & 0,035 \\
\hline STUD & 0,000 & 0,064 & 0,022 \\
\hline NAK_B+R & 0,217 & 0,111 & 0,042 \\
\hline APR_B+R & 0,239 & 0,132 & 0,036 \\
\hline JED_B+R & 0,163 & 0,113 & 0,101 \\
\hline DOMENY & 0,008 & 0,001 & 0,001 \\
\hline WYNAL & 0,022 & 0,042 & 0,008 \\
\hline WZORY & 0,042 & 0,012 & 0,034 \\
\hline OT_BZ & 0,076 & 0,049 & 0,027 \\
\hline LIN_AUT & $\mathbf{0 , 2 5 9}$ & $\mathbf{0 , 2 4 3}$ & $\mathbf{0 , 5 2 4}$ \\
\hline ZAK_TECH & $\mathbf{0 , 5 7 5}$ & $\mathbf{0 , 5 7 8}$ & $\mathbf{0 , 7 4 3}$ \\
\hline WSP_PRZEM & $\mathbf{0 , 5 6 9}$ & $\mathbf{0 , 7 2 0}$ & $\mathbf{0 , 6 4 3}$ \\
\hline WYS_TECH & 0,025 & 0,015 & 0,002 \\
\hline ŚRED_W_TECH & 0,000 & 0,069 & 0,000 \\
\hline ŚRED_N_TECH & 0,060 & 0,053 & 0,015 \\
\hline
\end{tabular}

Źródło: opracowanie własne 
TYPOLOGIA MIAST

Typologię miast z wykorzystaniem analizy struktur potencjału innowacyjnego przeprowadzono na podstawie dwóch pierwszych składowych głównych. Prezentują one główną linię podziału pomiędzy rodzajami potencjału innowacyjnego występującego $\mathrm{W}$ analizowanych ośrodkach - pierwszym opartym na rozwiniętym sektorze badawczym i drugim opartym na zasobach przedsiębiorstw przemysłowych. W ramach tego podziału stworzone zostały cztery podstawowe typy potencjału innowacyjnego. Ze względów metodologicznych cztery miasta nie wzięły udziału w analizie, jednakże w przypadku Warszawy i Płocka autor uznał, iż warto je przedstawić bazując na interpretacji poszczególnych zmiennych (ryc. 2-4).

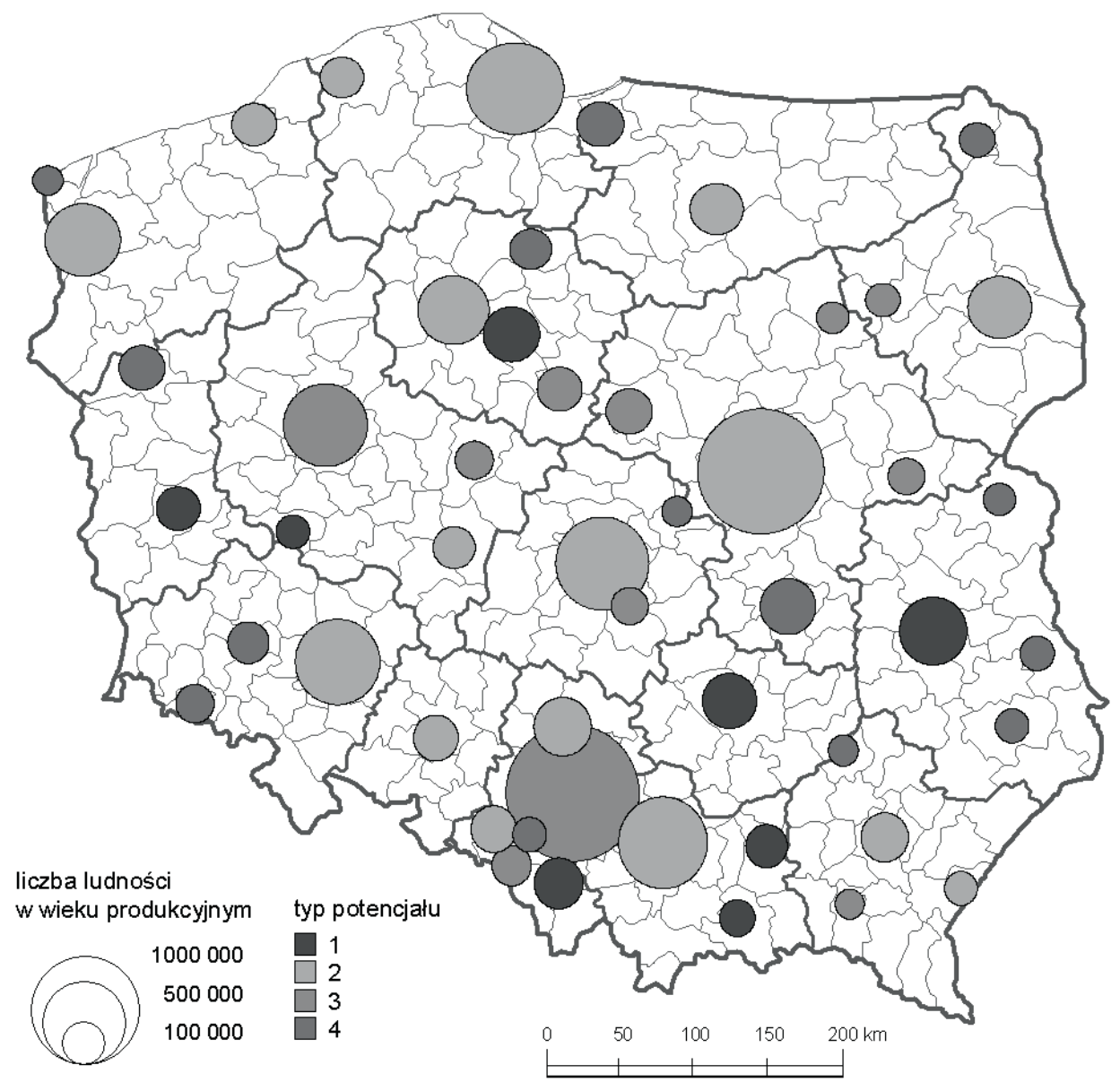

Ryc. 2. Typologia miast ze względu na typ potencjału innowacyjnego w $2000 \mathrm{r}$.

Źródło: opracowanie własne 


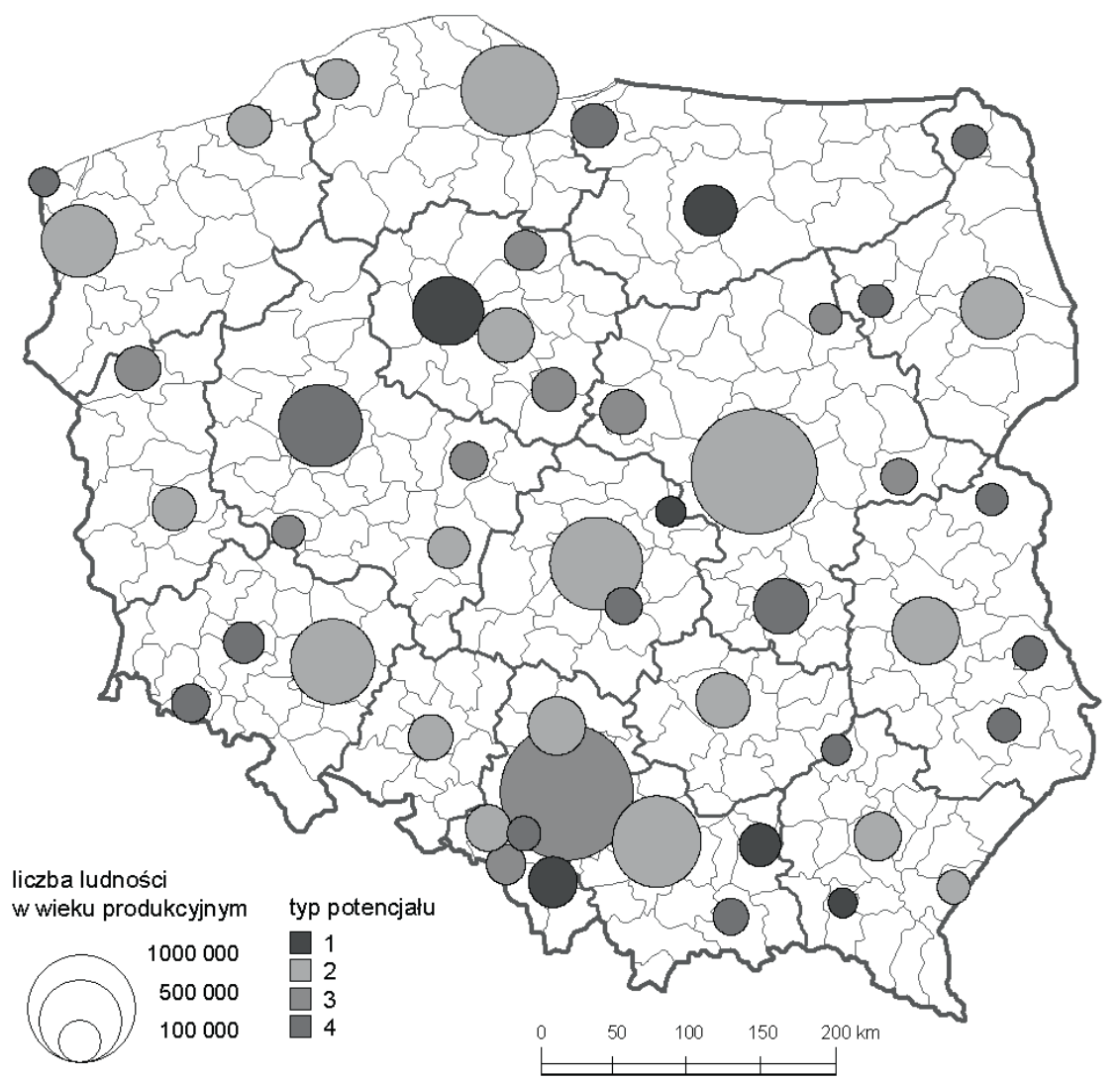

Ryc. 3. Typologia miast ze względu na typ potencjału innowacyjnego w $2004 \mathrm{r}$.

Źródło: opracowanie własne

Zgodnie z analizą wzięto pod uwagę najważniejsze mierniki i ich wartości charakterystyczne dla każdej z dwóch składowych głównych. Porównując te wartości ze zmiennymi dla obu miast przyporządkowano je w każdym z przekrojów czasowych do odpowiedniego typu.

Pierwszy typ (1) charakteryzuje się wysokim wskaźnikiem obu podstawowych rodzajów potencjału innowacyjnego, czyli zarówno opartego na rozwiniętym sektorze badawczym jak i dobrze prezentujących się zasobach przedsiębiorstw przemysłowych. Ośrodkom tym udało się zachować równowagę pomiędzy tymi dwoma wymiarami potencjału innowacyjnego. W roku 2008 były to: Bielsko-Biała, Skierniewice, Olsztyn, Krosno oraz Tarnów.

Miasta drugiego typu potencjału innowacyjnego (2) odznaczają się rozwiniętym sektorem badawczym i jednocześnie słabymi zasobami przedsiębiorstw przemysłowych. Obecność największych ośrodków (Warszawa, Kraków, Wrocław, Poznań, Trójmiasto) w ramach drugiej grupy należy tłumaczyć coraz mniejszym udziałem przedsiębiorstw przemysłowych w ich strukturze gospodarczej. 


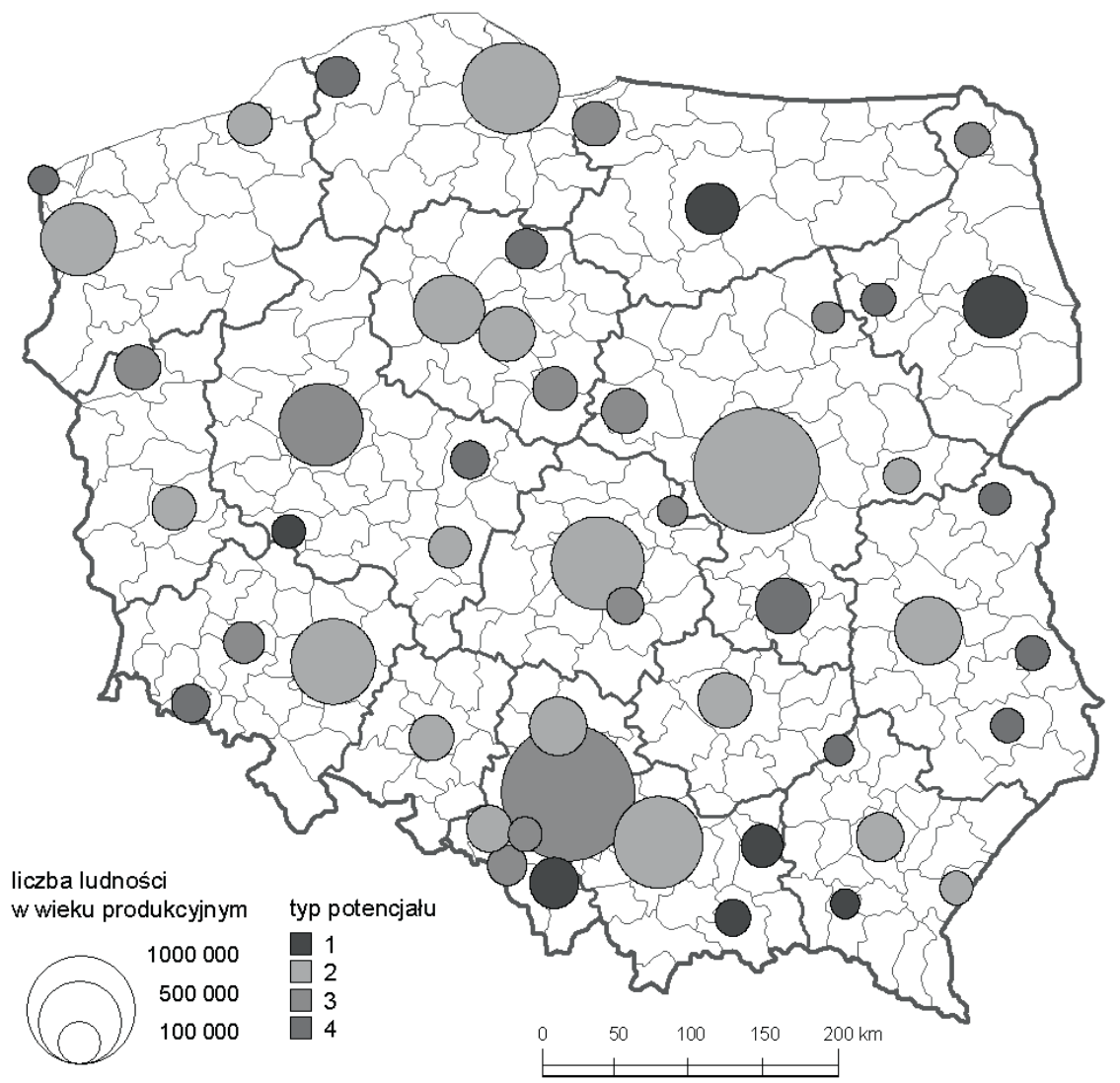

Ryc. 4. Typologia miast ze względu na typ potencjału innowacyjnego w $2008 \mathrm{r}$.

Źródło: opracowanie własne

W miastach tych coraz mocniej dominuje sektor przedsiębiorstw usługowych, który ze względu na problemy metodologiczne ${ }^{2}$ nie mógł być tak dobrze ujęty jak sektor przedsiębiorstw przemysłowych. W 2008 roku poza wyżej wymienionymi ośrodkami znalazło się 16 miast: Białystok, Bydgoszcz, Częstochowa, Lublin, Łódź, Opole, Radom, Szczecin, Toruń i Zielona Góra.

Trzeci typ (3) jest przeciwieństwem drugiego. W tych przypadkach ośrodki mają słabo rozwinięty potencjał innowacyjny sektora badawczo-rozwojowego, za to bardzo dobre zasoby przedsiębiorstw przemysłowych. Przede wszystkim są to mniejsze miasta o charakterze przemysłowym, takie jak Płock, Przemyśl czy Konurbacja Górnośląska. Łącznie w 2008 roku było to 13 ośrodków, czyli (poza wyżej wymienionymi) Gorzów Wielkopolski,

${ }^{2}$ Obecnie w Polsce badania dotyczące potencjału innowacyjnego w przedsiębiorstwach usługowych prowadzone są jedynie na potrzeby projektów zamawianych, gdzie uzyskanie danych odbywa się na podstawie ankietowania reprezentacyjnej grupy podmiotów gospodarczych. 
Jastrzębie-Zdrój, Legnica, Leszno, Nowy Sącz, Ostrołęka, Piotrków Trybunalski, Przemyśl, Rybnik, Suwałki, Włocławek, Żory.

Ostatni typ (4) charakteryzuje się niskim potencjałem opartym na sektorze badawczym, a także nikłymi zasobami przedsiębiorstw przemysłowych. Miastom tym nie udało się rozwinąć znacząco żadnego z obu podstawowych wymiarów potencjału innowacyjnego, mimo iż wiele z nich zanotowało wzrost SWPI. Jednakże wzrost ten nie był wystarczający by nadgonić dystans do pozostałych miast. W 2008 roku do typu 4 należało 15 następujących ośrodków: Biała Podlaska, Chełm, Elbląg, Grudziądz, Jelenia Góra, Kalisz, Kielce, Konin, Koszalin, Łomża, Siedlce, Słupsk, Świnoujście, Tarnobrzeg, Zamość.

\section{DYSKUSJA WYNIKÓW I WNIOSKI}

Pojęcie potencjału innowacyjnego nie jest zbyt popularne w naukach społeczno-ekonomicznych. Niewiele jest opracowań starających się zgłębić tę tematykę, szczególnie w polskiej literaturze naukowej. Ujęcie zaproponowane przez Guzika (2004) jest zbyt wąskie, zaś przez Ciok i Dobrowolską-Kaniewską (2009) zbyt szerokie. Autor w niniejszej pracy starał się uzyskać w miarę dużą liczbę odpowiednio dopasowanych cech opisujących potencjał innowacyjny, co jednak okazało się być dużym wyzwaniem, ze względu na trudną dostępność danych. Jednakże uzyskane wskaźniki umożliwiły badanie struktury potencjału innowacyjnego, co z kolei pozwoliło na opracowanie typologii miast, gdzie wyróżniono cztery podstawowe typy.

Pierwszy typ charakteryzuje się wysokimi wskaźnikami obu podstawowych rodzajów potencjału innowacyjnego, czyli zarówno opartego na rozwiniętym sektorze badawczym jak i odpowiednich zasobach przedsiębiorstw przemysłowych. Ośrodkom tym udało się zachować równowagę pomiędzy dwoma najważniejszymi wymiarami potencjału innowacyjnego. Mała liczba takich miast wskazuje na istnienie wyraźnej dychotomii wśród Polskich miast w zakresie posiadanego potencjału innowacyjnego. Do tej grupy zostały zaliczone ośrodki: Bielsko-Biała, Skierniewice, Olsztyn, Krosno oraz Tarnów. W mieście Bielsko-Biała to głównie przedsiębiorstwa (zarówno te mniejsze, założone i rozwijane przez lokalnych przedsiębiorców, jak i te duże przedsiębiorstwa międzynarodowe, które rozpoczęły swoją produkcję) są odpowiedzialne za tak wysoki wskaźnik potencjału innowacyjnego. Dodatkowym atutem jest dość duża liczba szkół wyższych i instytucji badawczo-rozwojowych jak na miasto o takiej liczbie mieszkańców. W konsekwencji wiele z tych instytucji współpracuje ściśle z przedsiębiorcami, co owocuje ciekawymi projektami i udanymi innowacjami wprowadzanymi na rynek.

Pozostałe ośrodki, jak wskazują wartości wskaźników cząstkowych, rozwijają dobrze poszczególne aspekty potencjału innowacyjnego, choć można zaznaczyć ich cechy charakterystyczne. Tarnów jest ważnym ośrodkiem przemysłowym (najważniejsze branże: chemiczna, maszynowa i spożywcza), gdzie zadbano także o rozwój otoczenia innowacyjnego (samych parków przemysłowych jest 4). Olsztyn jest jednym z najlepiej rozwiniętych mniejszych ośrodków akademickich w Polsce, a także ważnym ośrodkiem przemysłu oponiarskiego, meblarskiego i spożywczego. Skierniewice uznawane są za polskie centrum nauk w zakresie ogrodnictwa, jak i posiadają wiele dobrze prosperujących przedsiębiorstw z bran- 
ży maszynowej, elektronicznej i spożywczej. Krosno mimo swej niedużej liczby mieszkańców to największy krajowy ośrodek przemysłu szklarskiego, jedno z ważniejszych miast „Doliny Lotniczej”, a także miejsce działalności wielu ważnych podmiotów, m.in. z branży samochodowej i naftowej. Tu także znajduje się m.in. podstrefa specjalnej strefy ekonomicznej Krakowskiego Parku Technologicznego i inkubator technologiczny. Dokładniejsza analiza rozwoju tych miast w opinii autora może przynieść ciekawe wnioski.

Miasta drugiego typu potencjału innowacyjnego odznaczają się rozwiniętym sektorem badawczym i jednocześnie słabymi zasobami przedsiębiorstw przemysłowych. Obecność największych ośrodków tej grupy należy tłumaczyć coraz mniejszym udziałem w ich strukturze gospodarczej przedsiębiorstw przemysłowych. W grupie tej znajdują się takie aglomeracje, jak Warszawa, Kraków, Wrocław, Poznań, Trójmiasto, Białystok, Bydgoszcz, Częstochowa, Lublin, Łódź, Opole, Radom, Szczecin, Toruń i Zielona Góra. Ośrodki te będą rozwijały się w zakresie przedsiębiorstw usługowych, dlatego wszelkie działania władz lokalnych powinny być podejmowane w celu zwiększenia atrakcyjności dla takiej działalności gospodarczej. Należy także umiejętnie przeprowadzić dyfuzję tych procesów na całe obszary metropolitalne.

Trzeci typ potencjału innowacyjnego można uznać za przeciwieństwo drugiego. Ośrodki będące w tej grupie mają słabo rozwinięty potencjał innowacyjny oparty na sektorze badawczym, za to bardzo dobre zasoby przedsiębiorstw przemysłowych. Przede wszystkim są to mniejsze miasta o charakterze przemysłowym, które zawdzięczają tak rozwinięty potencjał innowacyjny głównie obecności dużych przedsiębiorstw przemysłowych. W 2008 roku ten typ potencjału innowacyjnego reprezentowało 13 następujących ośrodków: Płock, Przemyśl, Konurbacja Górnośląska, Gorzów Wielkopolski, Jastrzębie-Zdrój, Legnica, Leszno, Nowy Sącz, Ostrołęka, Piotrków Trybunalski, Przemyśl, Rybnik, Suwałki, Włocławek, Żory. Do tych miast powinny być skierowane szczególne działania polegające na wykorzystaniu istniejącego potencjału innowacyjnego oraz większej jego integracji ze środowiskiem naukowym. W wielu z nich podejmowane są już takie próby poprzez tworzenie odpowiednich instytucji. Najbliższe lata pokażą, które z tych ośrodków dobrze wykorzystały swoją szansę i umiejętnie wsparły w modernizacji przedsiębiorstwa przemysłowe.

Ostatni typ charakteryzuje się niskimi wartościami potencjału opartego na sektorze badawczym, a także nikłymi zasobami przedsiębiorstw przemysłowych. Występuje on w przypadku 15 analizowanych miast. Ośrodki zgromadzone w tej grupie są bardzo różne i zapewne dla większości z nich rozwój potencjału innowacyjnego jest jedną z kilku możliwych opcji. W pierwszej kolejności powinno się jednak zwrócić uwagę na inne zalety i możliwe ścieżki rozwoju (jak w przypadku Świnoujścia rozwój turystyki i obsługa portu gazowego). Dopiero w drugiej kolejności należałoby rozpatrzyć czy rozwój potencjału innowacyjnego to dobry pomysł na budowanie potencjału endogenicznego.

$\mathrm{Na}$ koniec warto zwrócić uwagę, że na 50 analizowanych ośrodków ${ }^{3}$ tylko dla 17 zanotowano zmianę typu pomiędzy rokiem 2000 a 2008. W większości tych miast (7) zmiana nastąpiła z czwartego typu na trzeci. Jedynie dwa miasta (Olsztyn i Krosno) zdołały przełamać istniejącą dychotomię i na koniec analizowanego okresu znalazły się w pierwszym typie o zrównoważonym potencjale innowacyjnym. Trzy ośrodki (Toruń, Zielona Góra i Bydgoszcz) zmieniły typ z pierwszego na drugi, czyli nastąpiła dominacja potencjału in-

\footnotetext{
${ }^{3}$ Konurbacja Górnośląska i Trójmiasto traktowane są jako dwa ośrodki.
} 
nowacyjnego opartego na sektorze badawczym. W 6 miastach nastąpiła za to zmiana z 2 lub 3 typu na ostatni typ. Tak mała liczba ośrodków, które zanotowały zmiany w typie potencjału innowacyjnego wskazuje, iż jest on kształtowany przez „procesy długiego trwania”.

\section{Literatura}

Ciok S., Dobrowolska-Kaniewska H., 2009, Polityka innowacyjna państwa a regionalny potencjat innowacyjny. Przykład Dolnego Śląska, Instytut Geografii i Rozwoju Regionalnego Uniwersytetu Warszawskiego, Wrocław.

Guzik R., 2004, Przestrzenne zróżnicowanie potencjału innowacyjnego w Polsce, [w:] M. Górzyński, R. Woodward (red.), Innowacyjność polskiej gospodarki, Zeszyty Innowacyjne 2, CASE Centrum Analiz Społeczno-Ekonomicznych, Warszawa, s. 33-36.

Marinova D., Philimore J., 2003, Models of innovation, [w:] L.V. Shavinina (red.), The International Handbook on Innovation, Oxford, Elsvier, s. 44-53.

Markowski T., 2005, Wspótczesne uwarunkowania polityki innowacyjnej w regionach, [w:] F. Kuźnik (red.), Studia regionalne w Polsce, Wyższa Akademia Ekonomiczna, Katowice.

Strahl D., 2006, Metody oceny rozwoju regionalnego, Wydawnictwo Akademii Ekonomicznej im. Oskara Langego we Wrocławiu, Wrocław.

Zeliaś A. (red.), 2000, Taksonomiczna analiza przestrzennego zróżnicowania poziomu życia w Polsce w ujęciu dynamicznym, Wydawnictwo Akademii Ekonomicznej w Krakowie, Kraków.

\section{Typology of cities based on innovation potential}

The article is an attempt of a detailed analysis of the innovation potential for 65 cities with county rights in the years 2000, 2004, and 2008. For this purpose, the variables were gathered from over twenty six different sources. On the basis of principal components analysis, an analysis of the innovative potential structure was carried out. The typology uses two principal components, reflecting the basic division in the structure of the innovative potential of the analyzed cities. In the results four types are presented, assigned to cities surveyed in different years.

\section{Dr Piotr Siłka}

Polska Akademia Nauk

Instytutu Geografii i Przestrzennego Zagospodarowania Kraju

Zakład Przestrzennego Zagospodarowania

e-mail: psilka@igipz.pan.pl 